UDC 342.7

DOI https:/ / doi.org/10.32841/ILA.2021.25.07

\author{
IGNATIEVA A. I., \\ Candidate of Pedagogical Sciences, \\ Lecturer at the Department of General Military Disciplines \\ Military Law Institute \\ of Yaroslav Mudryi National Law University
}

\title{
FEATURES OF PERSONAL RIGHTS AND FREEDOMS IN THE UNITED STATES
}

Summary. The article highlights, that the central place in the system of organizational and legal guarantees for the protection of constitutional personal rights and freedoms in the United States is occupied by the judiciary, which is a means of protecting and protecting rights from violation by law enforcement agencies.

In accordance with international human rights standards, all policing must be guided by the principles of legality, according to which the exercise of any police authority must be carried out in accordance with the law and on its basis; the need for the police to exercise their powers only to the extent strictly necessary to achieve a legitimate law enforcement purpose; proportionality: the exercise of authority must be proportionate to the seriousness of the offense or the achievement of the purpose of the police; and accountability that police officers should be held accountable for their compliance with the law in the performance of their duties and responsibilities.

Despite Washington's desire to play the role of an exceptional leader in the protection and protection of human rights and freedoms, the human rights situation in the United States leaves much to be desired. In some respects, compared to 2018, there is a deterioration. The systemic problems of American society are only getting worse. These include racism and discrimination against immigrants, rampant xenophobia and rising extremism, prejudice against the judiciary, ill-treatment of prisoners, mass surveillance of citizens, control and suppression of the media, and the imperfection of the electoral system.

The American concept of civil rights and freedoms is characterized by a large number of sources, religious and ethical norms and ideals, the principles of Roman law, English common law.

The review of the human rights situation in a country is based on government reports, information from independent experts and UN expert groups on human rights, as well as information from regional and national non-governmental organizations. All these data are collected in a separate document provided to the members of the Human Rights Council.

Independent UN experts have stated that the United States, where there is structural discrimination on the grounds of race, "remains segregated by society". The document expresses concern over racist demonstrations organized by members of white nationalist and neo-Nazi groups that promote white supremacy and incite racial hatred. Among other issues that require attention, the review notes the forced separation of migrant families as a punitive means of deterring illegal entry into the country, which is contrary to international human rights norms and standards.

Key words: features, personal rights and freedoms, views, national legal procedures, moral claims, integral part, norms and standards, discrimination. 
Problem statement in general form. The phrase "human rights" can be used in an abstract and philosophical sense, either as a designation of a specific category of moral claims, that all people can invoke, or, more pragmatically, as a manifestation of these claims in positive law, for example, as a constitutional guarantee to hold governments accountable in accordance with national legal procedures. While the first understanding of this phrase can be referred to as "human rights", the second is described here as "human rights law" [1, p. 5].

Analysis of recent researches. It should be noted that despite the almost three hundred-year history of the United States, in the science of constitutional law, the issue of the concept and list of civil rights according to the American concept is still the subject of discussion. The most famous interpretations of scientists G. Hart, A. Michaeljon, N. Dossen, A.M. Karimsky, V.G. Kalensky, judges W. Douglas, G. Black, W. Holmes, etc.

Formulating the goals of the article. The purpose of the article is to consider the main features of human rights in the United States presented in the scientific literature.

Presenting main material. While the origin of "human rights" lies in the nature of man himself, as articulated in all major world religions and moral philosophy, "human rights law" is a more recent phenomenon that is closely associated with the rise of liberal views, democratic state. In such states, the majority approach legitimizes legislation and the increasingly bureaucratic functioning of the executive branch. However, the majority may sometimes have little respect for "numerical" minorities such as convicted criminals, linguistic or religious groups, non-citizens, indigenous peoples and the socially stigmatized. Therefore, it becomes necessary to guarantee the existence and rights of a numerical minority, vulnerable and powerless. This is achieved by agreeing the rules governing society in the form of a constitutionally enforceable and enforceable bill of rights, which contains fundamental human rights for all. This bill of rights creates a "human rights law" that becomes an integral part of the legal system and transcends ordinary laws and executive action [3, p. 22].

Functions, methods and forms of police activity in relation to protection of constitutional personal rights and freedoms in the United States. It is determined that U.S. police of all levels of jurisdiction perform functions, that are manifested in its powers: patrol-administrative, detective, preventive and special. The first three are purely police, and a special, which is to provide the police with a wide range of services to the public, called quasi-police.

The powers of the police are exercised through forms (legal, organizational and logistical) and methods (general and specific) activities. Legal forms include constitutional and law enforcement; organizational - internal-organizational and external-organizational. The general methods of policing include the belief, that direct guidance, encouragement and coercion; specific - police supervision, direct police coercion, police assistance, etc.

The most common method of police activity in the field of protection today constitutional personal rights and freedoms is a method of policing assistance. 
Federal police units have functions to stop, detection and investigation of crimes and offenses that encroach on state system, financial and economic system of the country and environmental security, that are components of the system of protection of constitutional personal rights and freedoms. State law enforcement agencies perform security-related tasks highways and coordination of activities and methodological support of local law enforcement agencies of the respective state. Patrol-administrative function and special function (provision assistance to persons in extreme situations) are most characteristic of local police units that exercise a significant amount of authority in the field protection of constitutional personal rights and freedoms, as there are the most close and aware of the problems of local residents.

Among the most promising activities of the US police in the field protection of constitutional personal rights and freedoms is considered scientific substantiated direction of communal activity of police (community policing), that is to establish partnerships with the local population for the purpose prevention of offenses and emergencies, improving the quality of life (as a result of such activities) on the territory of the respective community.

It is concluded, that the nature and scope of functions, the specificity of forms and methods of policing to protect constitutional personal rights and human freedoms are determined by the level of jurisdiction of the relevant authorities' law and order and the peculiarities of their legislative support, the number and social structure of the population of a certain service area.

The United States in the field of protection of constitutional personal rights and freedoms it was emphasized, that the reason for the severe restrictions on police rights was fears. American society usurpation of power and concentration of excess powers in one hand. Due to the restriction of police rights, society seeks exercise control over it. It is stated that authority, duties and jurisdiction police officers are strictly limited by law because of Anglo-American legal tradition gives priority to individual freedoms as a whole with active public control, including over the police. As a result, the American police approach today has a high degree of decentralization. The responsibility of the US police is proposed to be considered in a narrow and broad meaning. In the narrow sense, responsibility is administrative (disciplinary), civil and criminal, which occurs for non-compliance, improper execution, negligence or outright violation police constitutional personal rights and freedoms. It is established that today in the United States are actively used civilian police responsibility, which entails the duty of a police officer or his department or the educational institution in which he attended professional training, to compensate the damage caused to the person as a result wrongful acts or omissions.

Liability in the broadest sense implies not only legal but and the moral and political responsibility of police officers, as well as their accountability and controllability. They are subject to control by the USA police management of police departments, state bodies (court, presidential and Senate commissions) and society. 
According to the subjects of control, the following types are defined: internal (activities of internal investigation units) and external (activities state bodies, public non-governmental, human rights organizations, voluntary formations of police officers and residents of territorial communities, creation of civilian police academies, media activities).

It is concluded, that the most effective type of control activities of the USA police to protect constitutional human rights and freedoms is recognized as public, as it is fully carried out locally levels that allow you to take into account.

Inter-American Convention on Human Rights (Inter-American Convention, Convention) is, like the European Convention, a multilateral international treaty. The list of rights and freedoms contained in the Convention does not go beyond traditional civil and political rights, but, already enshrined in the Covenant on Civil and Political Rights. In the same time this list is much wider than in the European Convention. In particular, in Inter-American Convention contains such rights as the right to a name (Art. 18), the rights of the child (Article 19), the right to citizenship or nationality (Article 20), the right to equal protection of the law (Art. 24), the right to asylum (Clause 7, Art. 22), etc. war, the emergence of danger to the state or other emergency circumstances that endanger independence or security state party, it can take measures derogating from its obligations under the Convention in compliance with its requirements (Art. 27) [4].

The process of law enforcement in the United States, as well as normative consolidation of constitutional human rights and freedoms, took place "from below" - from the creation of local to state and federal police. The history of the development of the US police is connected with the problem of constitutional human rights and freedoms and the social struggle for them. The effectiveness of the protection of constitutional human rights and freedoms is closely linked to the professional education of U.S. police officers, as evidenced by the decisions of presidential and Senate commissions, which drew attention to the unsatisfactory level of police training as a cause of human rights violations. There is no single regulatory regulation in the United States police activities to protect constitutional human rights and freedoms, due to the decentralized nature of its organization. The most important regulations in this area are the federal Constitution. The second most important legal act is the decision of the Supreme Court. There is a list of constitutional personal rights and freedoms that are subject to the activities of the USA police (in order of importance): the right to life, property, liberty and security of person, inviolability of home, freedom of conscience and religion.

Functions performed by the USA police to protect constitutional personal rights and freedoms, grouped into two groups: police (patrol-administrative, detective, preventive) and quasi-police (special). Emphasis is placed on the further evolution in a democratic society of police functions towards quasi-policing, which is carried out in close interaction with the local population and public organizations with their involvement in law enforcement activities through the implementation of various programs that define a new direction of police 
activity - communal policing, the essence, which is to transform the police from a punitive body into a service to provide services and solve the daily problems of the local population. Based on the current tasks and functions of the police to protect constitutional personal rights and freedoms, it is considered reasonable to rename in Ukraine police to police, which also provides for the harmonization of national legislation on law enforcement in accordance with world democratic standards.

An essential element in the government's relationship with its citizens is the maintenance and functioning of the criminal justice system. Protecting the fairness and integrity of the judiciary is an essential element of the rule of law. The Magna Carta and numerous bills of rights throughout human history bear witness to the importance of such justice. Of course, the Fourth, Fifth, Sixth and Eighth Amendments of the Bill of Rights to the Constitution of the United States of America directly address the issue of fairness in criminal trials, including requirements related to search and seizure (Fourth Amendment); protection against punishment for the same misconduct and against self-incrimination (Fifth Amendment); the right to a speedy and open trial with an impartial jury, the right to be informed of all charges, the right to confront a hostile witness, the right to due process to summon witnesses, and the right to legal assistance (Sixth Amendment); prohibition of excessive bail or fine, as well as gross and unusual punishment (Eighth Amendment). Perhaps the most important safeguard of personal rights from the state in a criminal court is the presumption of innocence. Likewise, the law - Habeas corpus-appellate conviction, criminal and fair sentencing, criminal and fair sentencing and subsequent sentencing and subsequent treatment of prisoners is vital [7].

In addition to the protection of constitutional human rights and freedoms by the police in the United States, there are violations of these rights, especially the rights of ethnic and racial minorities, refugees, and illegal migrants, as evidenced by discrimination and abuse of power, including unreasonable use of force. In order to effectively prevent such violations by the police of constitutional personal rights and human freedoms in the United States, there is a tendency to combine state, internal and public control through the activities of voluntary associations of police and non-governmental organizations.

The most important rules governing civil rights and freedoms are contained in the First Amendment to the USA Constitution, which regulates freedom of religion, speech, press, assembly. It acts as a legal, or rather, constitutional, basis for the process of formation and functioning of all non-state bodies and organizations, as an initial legal basis for the development and publication of various normative legal acts regulating the internal life and activities of these institutions. An important form of protection of civil rights and freedoms, the First Amendment reflects the principles of natural law and free government that played a huge role in shaping the concept of American civil rights and freedoms [5, p. 22].

Despite Washington's desire to play the role of an exceptional leader in protecting and ensuring human rights and freedoms, the human rights situation in 
the United States leaves much to be desired. In a number of aspects, compared to 2018, there is a deterioration. The systemic problems of American society are only getting worse. Among them - racism and discrimination against immigrants, rampant xenophobia and the rise of extremism, bias in justice, cruel treatment of prisoners in prisons, mass surveillance of citizens, control and suppression of media activities, imperfect electoral system.

Under the guise of the fight against terrorism, the United States disproportionately and indiscriminately uses military force on the territory of other states in violation of international humanitarian law. As a result of the use of unmanned aerial vehicles in the framework of the so-called anti-terrorist operations, civilians die.

The operation of the infamous USA military base at Guantanamo Bay is a direct testament to the American policy of "double standards" in the field of human rights. Unjustified arrests, extrajudicial executions, torture and other forms of treatment degrading human dignity - all these evidences of violations of international human rights principles and norms are diligently hushed up.

Although the number of death sentences and executions in the United States has gradually declined over the past few years, this figure remains high. Capital punishment is still used in 29 states, as well as at the federal level.

The number of convicts, who have undergone the death penalty since 1976 is 1.499 (of whom about 55.7\% are white, 34.2\% are African Americans, $10.1 \%$ are representatives of other races). The number of prisoners sentenced to death as of July 1,2018 was 2.738 .

According to the Death Penalty Information Centre (as of April 8, 2019), 7 people have been executed since the beginning of 2019 ( 3 in Texas, 2 in Alabama, 1 in Georgia, 1 in Florida). In 2018, 25 people from 8 states were executed [6].

International human rights institutions and mechanisms point to a large number of people wrongly sentenced to death. It is also noted that in some states, in the execution of death sentences, unapproved drugs are used, information about which was not disclosed.

At present, the idea of abolishing the death penalty is receiving more and more support in American society. In 2018, the Washington State Supreme Court ruled the death penalty as contrary to the state constitution. On the basis of this judgment, 8 previously imposed death sentences there were commuted to life imprisonment without the right to parole.

On 28 October 2020, Amnesty International raised concerns over the condition of human rights in the United States, and decided to monitor and expose the human rights violations related to protests during and after the 3 November United States elections.

On 9 November 2020, during the 3.5-hour session at the UN's main human rights body, the United States came under scrutiny for the first time in five years, regarding the detention of migrant children and the killings of unarmed black people. 
Conclusions prospects for further research. Consequently, the development of the institute of constitutional personal rights and human freedoms in the United States was significantly influenced by the jusnaturalist doctrine of human rights originated in Western Europe. The development of the institution of personal rights and human freedoms in the United States is due to the nature of the first colonies, the purpose of whose resettlement to a new continent was the desire to free themselves from religious persecution sign in the historical homeland and the organization of socio-economic life in the new lands on the basis of freedom and civic self-government as a natural human right, which later received legislative form in state constitutions, the federal constitution and amendments thereto. The only US legal act in the field of constitutional personal rights and freedoms is the US Constitution.

Although the text of the Constitution itself does not enshrine provisions on human rights and freedoms in general, the amendments to it (the Bill of Rights) that contain these provisions are organic; part of the US Constitution, and therefore, constitutional personal rights and freedoms in the United States fall under the protection of all constitutional acts of the country, including decisions of the Supreme Court.

The most effective and efficient guarantee of constitutional personal rights and freedoms in the United States is their judicial protection. Without denying the importance of the role of the court, the USA police do most of the work to protect law and order and combat crime, as well as to help people in extreme situations, which is a system of measures aimed at protecting constitutional human rights and freedoms.

\section{References:}

1. Caplan L. State Immunity, Human Rights and Jus Cogens: A Critique of the Normative Hierarchy Theory. American Journal of International Law, 2003. Vol. 97, No. 4.

2. Inter-American Convention (1999) on the Elimination of All Forms of Discrimination against Persons with Disabilities.

3. In Larger Freedom: Towards Development, Security and Human Rights for All, Report of the Secretary-General, UN Doc A/49/2019, 21 March 2019.

4. Human Rights Record of the United States in 2019. State Council Information Office of the People's Republic of China. March 2019. URL: http://www.chinahumanrights. org/html/2019/HRRUS_0315/12899.html6 (Last accessed: 15.02.2021).

5. Mike Campbell (Pvt) Limited and Others v Republic of Zimbabwe, Case SADCT 2/07, SADC Tribunal, 28 November, 2008.

6. UN Doc. A/RES/60/251 (para 13), 3 April 2006, recommending to the Economic and Social Council to "abolish" the Commission on Human Rights on 16 June 2006.

7. Права людини в Сполучених Штатах Америки. Нью-Йорк : Інститут демократії та співробітництва. 2014. С. 17-28. URL: http://argument.ru/images/ reports/19.pdf (дата звернення 15.02.2021).

Ігнатьєва А. І. Особливості особистих прав і свобод людини у США

Анотація. У статті зазначається, що центральне місце у системі організаційно-правових гарантій захисту конституційних особистих прав і свобод людини у США посідає 
судова гілка влади, яка $€$ засобом охорони й захисту прав від їх порушення з боку правоохоронних органів країни.

Відповідно до міжнародних стандартів у галузі прав людини всі дії поліції повинні керуватися принципами законності, згідно з якими будь-які поліцейські повноваження мають здійснюватися відповідно до закону і на його основі; необхідність, щоб поліція здійснювала свої повноваження тільки тією мірою, якою це необхідно для досягнення законної правоохоронної мети; співмірність: здійснення повноважень має бути пропорційним серйозності правопорушення або досягнення мети поліцейської діяльності; підзвітність, тому що співробітники поліції повинні нести відповідальність за дотримання ними закону під час виконання своїх повноважень і обов'язків. Незважаючи на прагнення Вашингтона грати роль виняткового лідера у справі захисту і забезпечення прав і свобод людини, ситуація в правозахисній сфері у США залишає бажати кращого. За низкою аспектів порівняно з 2018 роком спостерігається погіршення. Системні проблеми американського суспільства тільки посилюються. Серед них - расизм і дискримінація іммігрантів, розгул ксенофобії та підйом екстремізму, упередженість правосуддя, жорстоке поводження з ув'язненими в тюрмах, масове стеження за громадянами, контроль і придушення діяльності 3МI, недосконалість виборчої системи.

Американська концепція цивільних прав і свобод характеризується великою кількістю джерел, релігійно-етичних норм і ідеалів, принципів римського права, англійського загального права.

Огляд ситуації з правами людини в тій чи іншій країні грунтується на доповіді уряду, інформації незалежних експертів і експертних груп ООН з прав людини, а також на інформації регіональних і національних неурядових організацій. Усі ці дані збирають в окремий документ, який надають членам Ради з прав людини.

Незалежні експерти ООН констатували, що Сполучені Штати, де існує структурна дискримінація за ознакою раси, «залишаються сегрегованим суспільством». У документі висловлено занепокоєння расистськими демонстраціями, які організовують члени груп білих націоналістів, неонацистів, що пропагують перевагу білої раси і розпалюють расову ненависть. У числі інших проблем, що вимагають уваги, в огляді відзначається примусове розділення сімей-мігрантів як каральний засіб стримування нелегального в'їзду в країну, що йде врозріз з міжнародними нормами і стандартами в галузі прав людини.

Ключові слова: особливості, особисті права і свободи людини, погляди, національні юридичні процедури, моральні вимоги, складова частина, норми і стандарти, дискримінація. 